\title{
Ocular Adnexal Lymphoma pT4 TNM
}

\section{Finding v8}

National Cancer Institute

\section{Source}

National Cancer Institute. Ocular Adnexal Lymphoma pT 4 TNM Finding v8. NCI

Thesaurus. Code C140869.

Orbital adnexal lymphoma and extraorbital lymphoma extending beyond the orbit to adjacent structures, such as bone, maxillofacial sinuses, and brain. (from AJCC 8th Ed.) 